\title{
Empirical Studies on the Writing Abilities of Adolescents and Adults with Learning Difficulties
}

\author{
Noel Gregg and Jason Nelson
}

Scholarship from the fields of sociolinguistics, cognitive psychology, and neurolinguistics influence our understanding of the development of written expression across the lifespan. Neurolinguistics and cognitive psychology research provide evidence of the many different cognitive and language processes influencing writing tasks (Berninger \& Winn, 2006; Torrance \& Galbraith, 2006). Understanding how specific processes (e.g., working memory, executive functioning, orthographic awareness) influence different aspects of written expression performance directly informs our intervention and accommodation decision-making (Gregg, 2009). Strategic learning relies not only on the cognitive abilities of writers, but also their experiences, self-efficacy beliefs, and motivation for writing (Pajares \& Valiante, 20o6). Researchers applying sociolinguistic models lend verification of the affective, situational, and social variables influencing written expression (Prior, 2006), yet the boundaries between cognitive, linguistic, affective, and social processes are ambiguous. It is critical for professionals interested in the abilities of the adolescent and adult population struggling with written expression to remain informed by research from several theoretical perspectives.

\section{Definition of Written Expression}

Vygotsky (1986) wrote extensively about the complex process of writing and postulated that learning to write involves the mastering of cognitive skills within the development of new social understanding. To transform inner language to written text requires stepping outside of thought to the social context of the reader. Building upon Vygotsky's pioneering work, we recognize the significant influence of social context on individual achievement; he suggested that learning is situated in and mediated by (a) the cultural practices of the group, (b) the available tools for sense-making (whether physical/material, linguistic, discursive, or conceptual), and (c) the particular activities and activity systems in which learning occurs.

(C) KONINKLIJKE BRILL NV, LEIDEN, 2018 | DOI: 10.1163/9789004346369_006

This is an open access chapter distributed under the terms of the prevailing CC-BY-NC License at the time of publication. 
Written expression and the tools we now use to communicate written text are being redefined in the twenty-first century digital, multi-networked, and multi-tasking world of information data collection and ever changing communication platforms (National Research Council [NRC], 2012). Online writing competencies, such as proficiency with a variety of virtual platforms and social media tools, are essential for success in school, social life, and the workplace.

\section{Adolescent and Adult Writers}

Adolescents and adults may struggle with written expression dependent on shifting contexts or the demands posed by different discourse communities (NRC, 2012). Observed differences vary by individual profile and/or the text demands. Adult writers with specific cognitive processing disorders often demonstrate difficulties with written expression (Gregg, 2009), and insufficient writing instruction early in their schooling causes many low literacy adults to be unprepared for the demands of work situations (MacArthur, Greenberg, Mellard, \& Sabatini, 2010). While some individuals master out-of-school writing literacies (e.g., Facebook, Twitter, texting), they still could be lacking the writing proficiency necessary for success in higher education (NRC, 2012). This chapter integrates the research addressing these often-overlapping groups of struggling writers while recognizing that adults/adolescents who appear to struggle in one context may be adept in another.

\section{Persistence and Written Expression}

Contemporary researchers of motivation recognize the importance of a learner's cognitive profile, environment, and broader social and cultural experiences that affect persistence to complete writing tasks (Anderman \& Anderman, 2010). Motivation, persistence, and engagement with writing are defined differently depending upon a researcher's theoretical perspective and are at times used interchangeably. We chose to use the term "persistence", as it best describes the act of writing required of adolescents and adults. Many writers demonstrating learning disorders (LD) want to become proficient in writing, but often do not persist due to lack of opportunity and/or effective interventions. Some adults with literacy difficulties are less motivated to engage in writing tasks as a result of their histories with academic learning and social stereotyping (Guthrie \& Wigfield, 200o). However, it was not until the 1990s that motivation began to be integrated as a key component into cognitive mod- 
els of writing (Hayes, 1996; Zimmerman \& Risemberg 1997). More recently, the Hayes and Berninger (2014) writing framework (summarized in O'Rourke, Connelly, \& Barnett, this volume) identifies a few of the motivational factors closely associated with the language and cognitive processes critical to written expression. Persistence in developing writing skills is a continuous and complex learning process that significantly influences the educational and career aspirations of an individual.

Researchers provide evidence that skilled writers are more motivated to engage in writing tasks than less skilled individuals (Vrugt, Oort, \& Zeeberg, 2002), and often demonstrate more positive attitudes toward writing and greater belief in their ability to succeed on written expression tasks (Bandura, 1997; Pajares, 2003). Several specific aspects of persistence have been identified as critical to writing performance, including self-regulation (Butler \& Winne, 1995), self-efficacy (Bandura, 1977), and goal orientation (e.g., Pintrich \& Garcia, 1991). All of these constructs are interrelated factors influencing writing performance. It is critical to remember that the influence of each of these factors may be experienced differently depending on the individual's cognitive profile, experience, context, and activity demands. Writing demands vary from composing academic papers to Twitter tweets, requiring the individual to call upon different affective and cognitive abilities depending on the text requirements, which can either facilitate or constrain performance. Persistence with writing tasks is inter-related with an individual's affective response and cognitive processing abilities. Writing experiences may help to build an individual's identity as a writer, thus increasing self-confidence, self-efficacy and motivation to engage with new and unique writing activities (Dweck, 2002; Meyer \& Turner, 2006).

\section{Self-Regulation}

Difficulty self-regulating the demands of writing appears to be a significant risk factor for many adolescents and adults with LD (Gregg, 2009). In particular, these individuals often do not appear to maximize the skills and knowledge gained from past academic experiences. Pintrich (2000) defined self-regulated learning as "an active, constructive process whereby learners set goals for their learning and then attempt to monitor, regulate, and control their cognition, motivation, and behavior, guided and constrained by their goals and the contextual features in the environment" (p. 453). Many writers with LD apply restricted approaches to planning, producing, and revising text. Such writers often demonstrate difficulty accessing strategies and knowledge that can be coordinated and regulated to reach the writer's goals (Graham, 2006). An increasing body of research is providing evidence that when struggling adoles- 
cent and adult writers are taught specific strategies to increase their knowledge about writing, their writing performance improves (Graham \& Perin, 2007).

\section{Self-Efficacy}

Self-efficacy beliefs are integral to one's ability to self-regulate behavior and learning. The type most related to writing competence is referred to as academic self-efficacy, which refers to an individual's ability to manage and master academic expectations. Academic self-efficacy is a strong predictor of writing performance (Pajares, 2003); weaker writers possess a lower sense of selfefficacy than stronger writers (Vrugt et al., 2002).

\section{Specialized Writing Knowledge}

Empirical research provides evidence that adult knowledge of specialized features of written expression (e.g., sense of audience and genre structures) improves the quality of writing performance (NRC, 2012). In addition, writers using online context draw upon not only the specialized knowledge of traditional written text, but also of online structures such as hyperlinks, websites, and search engines (Zhang \& Duke, 2008).

\section{Sense of Audience}

Writers experiencing problems producing quality text often differ from their higher-achieving cohorts in the degree and manner in which they consider their audiences (Rubin \& Looney, 1990). Struggling writers tend to think infrequently of potential readers, and fail to use information about their readers even when it is available. The problems adolescents and adults with LD experience in revision and audience awareness are interdependent. To investigate a writer's sense of audience requires evaluation of the writer's voice, perceptions of the audience, and the context in which the writing occurred (Gregg, Sigalas, Hoy, Weisenbaker, \& McKinley, 1996). The writer, audience, and context are all involved in the dynamic creation of text and this leads to choices regarding concepts, vocabulary, style, and text organization.

Researchers have identified a number of social cognition skills required for developing sensitivity to audience in written language including content, execution, perspective taking, differentiation of voice, and organization of text (Gregg, 20o9). Deficits in any one (or more) of these areas have been shown to impact a writer's ability to identify and remain sensitive to a specific audience. Perspective-taking requires social inferencing and the ability to perceive or express various traits in others; deficits in perspective-taking are often char- 
acteristic of struggling writers. In a study exploring the relationship between sense of audience and LD among young adults, Gregg and McAlexander (1989) emphasized that certain cognitive profiles are more likely than others to cause problems with sense of audience. Interestingly, students with more severe linguistic deficits demonstrated greater sensitivity to sense of audience. However, their spelling and syntax errors often masked this strength in writing. Students with processing disorders impacting social cognition demonstrated the most difficulty with demonstrating sense of audience across writing tasks.

\section{Types of Text Structure}

Researchers provide evidence that increasing a struggling adult writer's knowledge about text structure can improve writing (Traxler \& Gernsbacher, 1993). Text structure refers to the means by which individuals organize their ideas in writing. Word and sentence structures, as well as function (purpose), can be very different depending on the chosen mode of writing (e.g., narrative, expository, persuasive). Complementing our chapter, O'Rourke, Connelly, \& Barnett (this volume) and Wengelin and Arfé (this volume) both explore the cognitive and linguistic relationships between reading and writing activities at the text level. From a very different orientation, Myhill and Jones (this volume), discuss the complementary dimensions of language process and social contexts influencing text construction. For our discussion, we draw upon the work of Halliday (1973) as a means of investigating text structure at the adult level. Halliday discussed three functions of adult language: ideational, interpersonal, and textual. The ideational function relates to the content or knowledge of what the writer is expressing. Usually, the more knowledge one brings to the writing task, the more fluent the writer. Interpersonal functions involve the writer's relationship to the audience (sense of audience). It is the textual function of writing that incorporates both the ideational and the interpersonal in order to construct meaning for the reader. Researchers examining the written text of adolescents and adults with LD note that these writers often demonstrate difficulty with executive processes, such as planning, monitoring, evaluating, and revising text structures (Graham \& Harris, 1999). Hayes and Berninger's (2014) writing framework discussed in O'Rourke et al. (this volume), identifies what they call a control level that allocates attention to planning, monitoring, evaluating and revising and also coordinates the use of writing schemas.

\section{Digitalk}

Researchers exploring the relationship between digital online reading and reading printed text emphasize that the processes are not isomorphic (Zhang 
\& Duke, 2008). The prior knowledge, inferential reasoning, and self-regulation strategies are different and often more complex with online reading. Evidence indicates that online reading requires flexible deployment of appropriate strategies, depending on purpose and stance, that vary from print reading (Cromley \& Azevedo, 2009). Therefore, it is not surprising that research on multimodal composing processes suggests that such writing requires new strategies to handle the increasing textual complexity (National Council of Teachers of English, 2008). Writers must now manage information presented and required for composing across a range of modes - audio, video, graphic, and with multiple new contexts and audiences (Ranker, 2008). Some have suggested that digital online composing might encourage new revision and selfmonitoring strategies (Li, 2006). Some research suggests that self-efficacy and self-determination influence the use and persistence of specific communication platforms (Coryell \& Chlup, 2007; Jacobson, 2008; NRC, 2012). The longterm action research writing program, Read to Learn (see Rose, this volume), is designed to increase the writing potential of struggling writers. It is an example of a writing model that focuses on learning as a social process. Use of this model provides an excellent framework for addressing many of the research questions exploring the relationship between digital reading and writing across a variety of learning environments adolescents and adults daily face.

Many adolescents and adults spend a great deal of time writing outside of the classroom, posting messages to social networks, chatting via instant messaging, and communicating by text messaging (Lenhart, 2010). Such digital writing requires the combination of written and conversational language and is referred to as digitalk (Turner, 2010, 2011). The features of linguistic structures demonstrated by those using digitalk do appear to reflect the ideational, interpersonal, and textual functions of traditional written language (Turner, Abrams, Katic, \& Donovan, 2014). The relationship between digitalk and literacy patterns appears to provide some interesting insight into writing abilities. Examining the relationship between texting and literacy skills in adolescents with and without specific language impairments (SLI), Durkin, ContiRamsden, and Walker (2011) found that adolescents with SLI wrote shorter text messages and used less digitalk in their messages. Normally-achieving readers and writers demonstrated greater use of digital language than adolescents with SLI, suggesting that digital linguistic growth appears to mirror standardized writing patterns.

Powell and Dixon (2011) investigated the relationship of textisms (the language used in text messages-abbreviations, single letters, or symbols) and spelling ability. They found that adults' exposure to misspellings had a negative impact on spelling ability, but their exposure to textisms had a positive effect. 
Their findings suggest that textism fosters metalinguistic awareness of how words are spelled. In addition, researchers have found that poor readers spent more time on their phones per day than strong readers, but strong readers used more textisms in their messages and were faster at reading a variety of different types of messages (Durkin et al., 2011). Research on the relationship between texting, textisms, and literacy skills of college students provides evidence that usage patterns vary across contexts (Drouin, 2011). In addition, Drouin found significant, positive relationships between text messaging frequency and literacy skills (spelling and reading fluency), but significant, negative relationships between textese usage in certain contexts (on social networking sites such as MySpace $^{\mathrm{mm}}$ and Facebook ${ }^{\mathrm{mm}}$ and in emails to professors) and literacy (reading accuracy). This suggests that college students demonstrating more advanced reading and spelling abilities may be using text messaging more frequently than young adults with less literacy proficiency. Crystal (2008) suggested that text messaging might not be an appealing medium for those with deficient literacy skills.

The relationship of textese usage across contexts appears to reflect the difficulty adults with low literacy demonstrate with code switching using traditional print formats. Drouin (2011) found that young adults who reported using more textese on social networking services and those who reported using more textese in emails to professors demonstrated lower reading decoding skills (Drouin, 2011). Similarly, Wood, Kemp, Waldron, and Hart (2014) found an association between young adults' tendency to make capitalization and punctuation errors in textese and their ability to select grammatically correct word representations (even after controlling for IQ and spelling ability). More research is certainly needed to examine the relationship of digital voice, sense of audience, and code switching abilities to literacy proficiency.

\section{Adult Literacy Research and Writing Performance}

U.s. federal agencies signaled a concern over the lack of research specific to the adult population with literacy challenges by increasing funding opportunities to investigate the barriers of this group of individuals. For example, in 2001, the National Institute of Child Health and Human Development, the National Institute for Literacy, and the Office of Vocational and Adult Education published a research solicitation committing a total of $\$ 18.5$ million over the 5 -year period from 2002 to 2006 to support adult literacy research (Miller, McCardle, \& Hernandez, 2010). While these agencies primarily funded research specific to reading in this population, they did encourage further empirical studies 
focusing on writing in adults. In addition, several federal agencies directed researchers to investigate the performance of learners in a range of settings not limited to formal adult basic education programs, but also to high school graduates enrolled in developmental college courses, and/or workplace literacy settings (Miller et al., 2010).

In the area of written expression, U.s. federal funding has primarily supported researchers investigating the instructional needs (i.e., face-to-face and virtual) of this diverse group of adult learners. Writing in community college has received some attention over the last few years as the retention and graduation rates for this population continue to be serious problems; from $40 \%$ to $60 \%$ of new community college students are required to take developmental writing courses and few reach the criteria to take credit-bearing courses (Bailey, Jeong, \& Cho, 2008). The majority of the research investigating underprepared writers has focused on strategy instruction rather than the exploration of the cognitive and linguistic processes involved in different writing areas (MacArthur \& Philippakos, 2013; Perin, 2013). Researchers advocating strategy instruction draw their support on the close relationship between the constructs of persistence and academic performance discussed earlier (i.e., self-regulation, self-efficacy, goal setting) as essential to improving writing (MacArthur \& Philippakos, 2013). While researchers have investigated additional cognitive and linguistic processes influencing adult populations demonstrating problems in reading decoding and reading comprehension, there continues to be less examination of the processes influencing adult writing. The one exception to this point pertains to the adolescent and adult population with documented LD, with most studies examining college students with LD.

\section{Empirical Studies on the Writing Performance of Adolescents and Adults with Learning Disorders}

In this section, we review empirical studies in which various aspects of writing have been explored with samples of adolescents and adults with documented LD. It should be first noted that the term learning disorders (i.e., learning disabilities, $\mathrm{LD}$ ) is used generally here to encompass a variety of more specific forms of disorders that often impact writing. These more specific forms include dysgraphia, dyslexia, and oral and written language learning disability (Berninger, 2009). In our review, we default to using the term learning disorders in a general way but highlight subtype issues when relevant for deepening understanding of specific writing issues. We structure our review according to the following four areas of writing: (1) handwriting, (2) spelling, (3) punctua- 
tion, grammar, and syntax, and (4) discourse. When relevant we also discuss the specific cognitive and linguistic processing abilities that may be disrupted, leading to problems in the specified aspect of writing. We also highlight how problems in each may cause difficulties in other aspects of writing and within the broader information processing system.

\section{Handwriting}

Adolescents and adults with LD have been found to have poorer handwriting legibility and slower handwriting speed than individuals without LD (Berninger, Nielsen, Abbott, Wijsman, \& Raskind, 2008; Hatcher, Snowling, \& Griffiths, 2002; see Tops, Callens, Van Cauwenberghe, Adriaens, \& Brysbaert, 2013, for a contrary finding). When adults with dyslexia in particular have been examined, their handwriting fluency has been shown to be lower than that of age-matched but not spelling-matched controls (Connelly, Campbell, MacLean, \& Barnes, 2006). Problems with handwriting are particularly characteristic of individuals with dysgraphia (Mather \& Wendling, 2011) and have been found to be more severe in men with LD than in women with LD (Berninger et al., 2008).

Problems with orthographic processing (i.e., awareness of and sensitivity to the visual representations of language) have been found to have a direct, negative effect on handwriting, whereas graphomotor planning difficulties indirectly influence handwriting via orthographic processing (Abbott \& Berninger, 1993). Orthographic processing difficulties are common among adolescents and adults with LD (Gregg, Bandalos, Coleman, Davis, Robinson, \& Blake, 2008); therefore, these may be key underlying processing issues leading to their handwriting problems. Problems with handwriting have been found to further disrupt information processing by consuming resources within the limitedcapacity working memory system, leaving fewer cognitive resources for meeting the higher-level demands of generating written text (Peverly, 2006). This disruption of working memory is particularly concerning because of the preexisting working memory deficits of many individuals with LD (Swanson \& Siegel, 2001).

Handwriting difficulties have been described as negatively impacting other aspects of writing for adolescents and adults with LD. Gregg (2009) stated that handwriting difficulties often lead to decreased written productivity and ideation. Handwriting difficulties have been shown to negatively influence overall essay quality ratings for adolescents and adults with LD (Connelly et al., 2006; Dockrell, Lindsay, \& Connelly, 20o9; Gregg, Coleman, Davis, \& Chalk, 
2007). Such difficulties have been shown to have a greater effect on quality ratings on timed essay exams than on formative class essays (Connelly, Dockrell, \& Barnett, 2005). Although it is clear that overall quality ratings are negatively affected by handwriting difficulties, further research is needed to determine the degree to which lower quality ratings are due to the effect of handwriting on raters' perceptions of competence versus its effect on higher-level processes influencing discourse complexity. Connelly and colleagues' (2006) study provides some insight into this issue. In this study, the handwritten essays of adults with dyslexia were typed up (spelling errors and cross-outs were preserved) prior to being rated for quality to reduce potential rater bias due to poor handwriting. They found that the overall essay quality scores of adults with dyslexia were lower than the scores of an age-matched control group but not lower than the scores of a spelling-skill-matched control group. Multiple regression analyses indicated that handwriting fluency was positively associated with overall essay quality ratings for the adults with dyslexia and the spelling-skill-matched, but not for the age-matched control group.

\section{Spelling}

Spelling is the aspect of writing that has received the most research attention in the adolescent and adult learning disorder literature. The majority of this research has used samples of adolescents and adults with reading disabilities (RD) or dyslexia, likely because word-level decoding (the core problem associated with dyslexia) and encoding are supported by similar underlying processing abilities (e.g., phonological and orthographic processing). In their meta-analysis of the adult RD literature, Swanson and Hsieh (2009) found large effect sizes for both spelling (encoding) problems $(d=1.57)$ and word reading (decoding) difficulties $(d=1.33)$. More recently, Tops, Callens, Bijn, and Brysbaert (2014) found effect size differences of greater than 2 when comparing the spelling skills of college students with and without dyslexia indicating that the spelling scores of adults with dyslexia were substantially lower than those of adults without dyslexia. Comparing samples of adults with LD in college or rehabilitation settings to adults without LD, Gregg et al. (1996) found that both LD groups possessed lower spelling skills than the group without LD and, surprisingly, that the spelling skills of college students with LD were lower than the skills of their counterparts in rehabilitation settings. Spelling differences among these groups have been found on both constrained, isolated word spelling tests and unconstrained, spontaneous writing samples, despite the ability of the writer to choose only words they know how to spell on the latter 
type of task. Within unconstrained writing samples, Coleman, Gregg, McLain, and Bellair (2009) found that adults with LD made spelling errors in 1 of every 40 words, compared to 1 in 143 for those without LD. Similarly, Leuenberger and Morris (1990) found that adults with LD made twice as many spelling errors in spontaneous writing samples compared to those without LD.

Spelling issues among adolescents and adults with LD negatively impact others' opinions of their writing in addition to causing difficulties in other aspects of writing. As noted by Gregg, Hoy, and Sabol (1988), mastery of the conventions of written language is perceived as a basic skill that indicates intellectual fitness for postsecondary education. Spelling errors by college students with LD have been shown to strongly influence raters' perceptions of these students' overall writing quality (Gregg et al., 2007). The spelling difficulties of adolescents and adults with LD may also impact overall writing quality via their influence on other aspects of writing. As an example, Cowen (1988) found that college students with LD often use simpler words in their writing to avoid spelling errors. Similarly, Tops et al. (2013) found these students avoid writing words longer than six letters. This strategy is problematic because vocabulary complexity has been shown to be the single best predictor of overall writing quality for adolescents and adults with LD (Gregg et al., 2007). Poor spelling among adults with dyslexia has also been shown to be associated with pausing and dysfluent writing (Wengelin, 2007).

Regarding processing issues associated with the spelling skills of adolescents and adults with LD, early research indicated that these individuals may draw upon orthographic knowledge to compensate for phonological processing problems influencing spelling (Pennington et al., 1986). More recent research has indicated that adolescents and adults with LD have been found to experience the most difficulty with orthographic exception words and to struggle to memorize orthographic patterns (Kemp, Parrila, \& Kirby, 2008; Meyler \& Breznitz, 2003). Both Coleman et al. (2009) and Tops et al. (2014) found that adolescents and adults with LD make more phonological, orthographic, and morphological errors in their spellings than do those without LD, suggesting that underdeveloped abilities in all three areas of processing tend to disrupt their spelling. These processing differences were found using both constrained and unconstrained tasks, although orthographic errors were found to be more common on word dictation tasks and morphological errors were more prevalent on sentence dictation tasks (Tops et al., 2014). 


\section{Punctuation, Grammar, and Syntax}

\section{Punctuation and Grammar}

Minimal research has been conducted in the areas of punctuation and grammar with adolescent and adult learning disorder samples. Of the studies that have been conducted, most have found that adolescents and adults with LD make more punctuation, capitalization, and grammatical errors (e.g., subjectverb and pronoun-antecedent agreement errors) than to do those without LD (Duques, 1989; Gregg, 1986b; Morris-Friehe \& Leuenberger, 1992; Tops et al., 2013; Vogel \& Moran, 1982). Because of these difficulties, adolescents and adults with LD have been described as prone to using punctuation sparingly (Vogel, 1985) and using less sophisticated grammatical structures and punctuation (Gregg, 2009). Additionally, nearly $80 \%$ of these individuals rely on others to proofread their written work (Smith, 1993).

Minimal research has also been conducted on the underlying processing issues that may lead to difficulties with punctuation and grammar for adults and adolescents with LD. In one of the only studies addressing this topic, Duques (1989) found that grammatical errors were prominent in both the spoken and written language of adults with $\mathrm{LD}$, but more pronounced in written language. She concluded that adults with LD often experience difficulties with general language production and that grammatical acceptability in written language is additionally influenced by the orthographic processing skills of adults with LD. Furthermore, Duques (1989) found that as the level of writing demand became more complex, grammatical acceptability decreased, leading her to speculate that short-term memory weaknesses may also play a role in their difficulty in producing more complex grammatical structures.

\section{Syntax}

Most of the research on syntax has focused on the syntactic maturity of adolescents and adults with LD. Although syntax is influenced by punctuation and grammar, it is thought to be a broader construct, referring to the ways in which words are assembled to create individual sentences (Gregg, 2009). Most studies on syntax have incorporated thematic or terminal unit ( $\mathrm{T}$ unit) analysis. A т unit, a single independent clause that may include dependent clauses, is mainly used to analyze syntax without consideration of punctuation and capitalization errors. No differences have been found in adolescents and adults with and without LD for length of T units (Gajar, 1989; Vogel, 1985; Vogel \& Moran, 1982). However, differences in complexity of syntactic structure have been found; adolescents and adults with LD have been found to use less complex syntactic structures (e.g., fewer subordinate clauses per $\mathrm{T}$ unit and fewer 
words per main clause) than their peers without LD (Vogel, 1985). Additionally, syntactic difficulties appear to be more problematic for some adolescents and adults with LD than others. Puranik, Lombardino, and Altmann (2007) found that adolescents and adults with language LD demonstrated more severe syntactic problems than did adolescents and adults with dyslexia, suggesting that individuals with broader oral language difficulties are more susceptible to experiencing syntactic problems in written language. Interestingly, participants with dyslexia in this study did not differ from participants without LD on any of the indicators of syntactic maturity.

\section{Discourse}

Although incorporating $\mathrm{T}$ unit analyses to examine syntactic maturity has been useful, these analyses have tended to treat writing as the expression of independent ideas rather than a combination of ideas expressed in a meaningful way (Gregg, Coleman, Stennett, \& Davis, 2002). Several studies have addressed the shortcomings of this approach by examining higher-level aspects of written expression at the discourse level; the majority have examined the cohesion and coherence of discourse-level written text produced by adolescents and adults with LD relative to their peers without LD. Additionally, total verbosity at the discourse level beyond simple $\mathrm{T}$ unit length has been examined.

\section{Cohesion}

Cohesion refers to the structure of written text beyond the sentence level (Gregg, 1986a). Gregg (1985) compared the written discourse of college students with $L D$ to that of basic writers (i.e., individuals with writing difficulties who did not meet the criteria for $\mathrm{LD}$ ) and writers without LD, to determine each group's use of cohesive ties (e.g., grammatical, transitional, and lexical ties). Results indicated no significant differences between the groups on either frequency or accuracy of any of the cohesive ties investigated.

In a follow-up study, Gregg and Hoy (1990) examined the use of cohesive referencing in the written discourse of college students with LD compared to underprepared writers and writers without LD. The authors defined cohesive referencing as skill at assigning roles to the speaker and the addressee in written discourse. Results indicated that college students with LD did not differ on this measure relative to college students without LD and that both of these groups demonstrated more sophisticated cohesive referencing than did the underprepared writers. They argued that college students with LD often possess strengths in the higher-level aspects of writing despite their 
problems with lower-level aspects of writing, citing observations that such writers generate ideas that are sophisticated in both meaning and structure. This argument was demonstrated by Connelly et al. (2006). In contrast, Gregg et al., (2007) found that the overall written discourse quality scores of college students with LD were lower than their peers without LD even when lowerlevel difficulties (e.g., spelling, handwriting, and grammar) were controlled; this difference manifested despite a structural equation analysis indicating that the dimensions of writing represented in expository discourse was similar for both groups. More research is needed to better understand these inconsistent findings.

\section{Coherence}

Coherence refers to the macrostructure of written discourse and is an indicator of how well written text comes together as a meaningful whole. In the only study examining this aspect of written expression with adults with LD, Gregg and Hoy (1989) compared college students with LD to underprepared writers and normally achieving writers. They also compared these groups on their comprehension of coherence (how well they comprehended logical verbal relationships, e.g., between words and sentences). Results indicated no differences between college students with LD and their normally achieving peers on comprehension of coherence measures, although both groups performed better than the underprepared writers without LD. The groups differed on their production of coherent text, with the normally achieving writers performing better than the other groups and the college students with LD demonstrating better coherence than the underprepared writers. Interestingly, college students with LD demonstrated the largest discrepancy between their comprehension and total coherence scores, leading the authors to conclude that these students possess strengths in their comprehension of coherent text structure but experience disruption in the processes necessary for producing coherent text.

\section{Verbosity/Fluency}

A final aspect of written discourse that has been examined with adolescent and adult LD samples is verbosity, or the total number of words used in written discourse. Verbosity has also been used as an indicator of the fluency of written discourse production, particularly under timed conditions. In a study of the timed essay writing of college students with LD, Gregg et al. (2007) found that these students wrote significantly shorter expository essays than did their peers without LD. Nearly $30 \%$ of individuals with LD were unable to complete their essays within the allotted time limit, whereas less than $10 \%$ of those 
without LD had such difficulty. Gregg et al. (2002) found that verbosity was one of the best discriminators between college students with and without LD and was strongly correlated with overall writing quality. They speculated that underlying cognitive and linguistic processing weaknesses of those with LD likely negatively impacted their access to words and syntactic structures, thus reducing their verbosity. Likewise, Coleman et al. (2009) found lower verbosity in expository writing in college students with LD and argued that orthographic and morphological processing weaknesses, slowing access to spelling patterns and vocabulary, were the likely mechanisms.

\section{Discussion}

Many theoretical arguments have been made relating various cognitive, affective, and linguistic processing issues to problems with written discourse; however, minimal empirical investigations have been conducted, particularly using adult samples with and without learning difficulties. Illustrative of this is McGrew and Wendling's (2010) recent review of the research on the relations between academic achievement and cognitive abilities delineated by the Cattell-Horn-Carroll ( $\mathrm{CHC}$ ) theory. The $\mathrm{CHC}$ is a hierarchical taxonomic conceptualization of cognitive abilities according to nine broad cognitive abilities (e.g., fluid reasoning, long-term storage and retrieval, auditory processing) and a plethora of narrow abilities (e.g., inductive reasoning, naming facility, and speech sound discrimination) that influence these broader abilities (see Schneider and McGrew, 2012, for a comprehensive discussion of CHC theory). In this review, empirical studies examining the relationship between math, reading, and $\mathrm{CHC}$ abilities, but not writing and $\mathrm{CHC}$ abilities, were reviewed (presumably due to the paucity of empirical research available for review on the latter relationships). In the few studies that have been conducted, both processing speed and crystallized knowledge have been consistently found to be significantly related to written expression across the lifespan (Floyd, McGrew, \& Evans, 2008; McGrew \& Knopik, 1993), and working memory has been shown to moderate structural complexity in writing in adulthood (Hoskyn \& Swanson, 2003). Although executive processes have been described as highly important for the higher-level aspects of written discourse (see Dehn, 2014, for a review), the relationship of these processes to the written expression of adolescents and adults underachieving in writing remains unexplored. This is extremely important to consider, because a great deal of instructional research focused on writing strategies is based on the assumptions (both theoretical and inferred) that these interventions on enhancing the executive processing skills of writers (e.g., 
self-monitoring, self-efficacy, self-regulation) are effective across the majority of individuals underachieving in writing (MacArthur \& Philippakos, 2013).

Vygotsky (1986) encouraged scholars to explore the importance of understanding the relationships between cognitive development and the current technological tools that mediate learning. The digital, multi-networked, multitasking, and constantly changing world of information and communication is placing even greater demands on literacy across social, school, and work situations. It is clear from recent research investigating adolescent and adult writers underperforming in written expressions that identifying effective strategies to enhance digitalk is an essential catalyst for better digital writing. Unfortunately, the emphasis in understanding digital writing has often focused on familiarity and/or access to the technology tools or communication platforms, rather than investigating effective digital writing strategies across different learners. Individuals underprepared in written expression often demonstrate some of those same problems with digital formats as they do with print (e.g., fluency, metalinguistics). Empirical research investigating strategies, interventions, and electronic mentoring models, focusing on enhancing access for adolescents and adults with literacy barriers to gain greater digital writing skills, is critical to furthering educational and career success for this population. There is evidence that socially and academically isolated individuals are often less likely than other adults to use new communication technologies (Bryant, SandersJackson, \& Smallwood, 2006). Therefore more research focused on the usage patterns and strategies effective for accessing and enhancing the use of information and communication technologies for the adolescent and adult population underprepared in writing is of critical importance for their advancement in our global environment.

\section{References}

Abbott, R., \& Berninger, V. (1993). Structural equation modeling of relationships among developmental skills and writing skills in primary and intermediate grade writers. Journal of Educational Psychology, 85, 478-508. doi:10.1037/0o22-0663.85.3.478

Anderman, E.M., \& Anderman, L.H. (2010). Classroom motivation. Upper Saddle River, $\mathrm{NJ}$ : Pearson.

Bailey, T., Jeong, D.W., \& Cho, S.W. (2008). Referral, enrollment, \& completion in developmental education sequences in community college (CCRC working paper No. 15). New York, NY: CCRC Publications.

Bandura, A. (1997). Self-efficacy: The exercise of control. New York, NY: W.H. Freeman and Company. 
Berninger, V.W. (2009). Highlights of programmatic, interdisciplinary research on writing. Learning Disabilities Research and Practice, 24, 69-8o. doi:10.1111/j.15405826 .2009.00281.x

Berninger, V.W., Nielsen, K.H., Abbott, R.D., Wijsman, E., \& Raskind, W. (2008). Gender differences in severity of writing and reading disabilities. Journal of School Psychology, 46, 151-172. doi:10.1016/j.jsp. 2007.02.007

Berninger, V.W., \& Winn, W.D. (2006). Implications of the advancements in brain research and technology for writing development, writing instruction, \& educational evolution. In C. MacArthur, S. Graham, \& J. Fitzgerald (Eds.), Handbook of writing research (pp. 96-114). New York, NY: Guilford.

Bryant, J.A., Sanders-Jackson, A., \& Smallwood, A.M.K. (2006) IMing, text messaging, \& adolescent social networks. Journal of Computer-Mediated Communication, 11, 577592. doi:10.1111/j.1083-6101.2006.00028.x

Butler, D.L., \& Winne, P.H. (1995). Feedback and self-regulated learning: A theoretical synthesis. Review of Educational Research, 65(3), 245-281. doi:10.3102/ oo346543065003245

Coleman, C., Gregg, N., McLain, L., \& Bellair, L.W. (2009). A comparison of spelling performances across young adults with and without dyslexia. Assessment for Effective Intervention, 34, 94-105. doi:10.1177/1534508318808

Connelly, V., Campbell, S., MacLean, M., \& Barnes, J. (2006). Contribution of lower order skills to the written composition of college students with and without dyslexia. Developmental Neuropsychology, 29, 175-196. doi:10.1207/s15326942dn29o1_9

Connelly, V., Dockrell, J.E., \& Barnett, J. (2005). The slow handwriting of undergraduate students constrains overall performance in exam essays. Educational Psychology, 25 , 99-107. doi:10.108o/0144341042000294912

Coryell, J.E., \& Chlup, D.T. (2007). Implementing e-learning components with adult English language learners: Vital factors and lessons learned. Computer Assisted Language Learning, 20(3), 263-278. doi:10.108o/o9588220701489333

Cowen, S.E. (1988). Coping strategies of university students with learning disabilities. Journal of Learning Disabilities, 21, 161-164. doi:10.1177/002221948802100308

Cromley, J.C., \& Azevedo, R. (2009). Locating information with extended hypermedia. Education Technology Research and Development, 57, 287-313. doi:10.1007/s11423oo8-9106-5

Crystal, D. (2008). Texting. ELT Journal, 62, 77-83. doi:10.1093/elt/ccmo8o

Dehn, M.J. (2014). Essentials of processing assessment (2nd Ed.). Hoboken, NJ: Wiley.

Dockrell, J.E., Lindsay, G., \& Connelly, V. (2009). The impact of specific language impairment on adolescents' written text. Exceptional Children, 75, 427-446.

Drouin, M.A. (2011). College students' text messaging, use of textese, \& literacy skills. Journal of Computer Assisted Learning, 27, 67-75. doi:10.1111/j.1365-2729.2010.00399.x

Durkin, K., Conti-Ramsden, G., \& Walker, A.J. (2011). Txt lang: Texting, textism use, 
\& literacy abilities in adolescents with and without specific language impairment. Journal of Computer Assisted Learning, 27, 49-57. doi:10.1111/j.1365-2729.2010.00397.x Duques, S.L. (1989). Grammatical deficiencies in writing: An investigation of learning disabled college students. Reading and Writing: An Interdisciplinary Journal, 1, 309325 .

Dweck, C.S. (2002). Messages that motivate: How praise molds students' beliefs, motivation, \& performance (in surprising ways). In J. Aronson (Ed.), Improving academic achievement: Impact of psychological factors on education (pp. 61-87). Orlando, FL: Academic Press.

Floyd, R.G., McGrew, K.S., \& Evans, J.J. (2008). The relative contributions of the Cattell-Horn-Carroll cognitive abilities in explaining writing achievement during childhood and adolescence. Psychology in the Schools, 45, 132-144. doi:10.1002/pits .20284

Gajar, A.H. (1989). A computer analysis of written language variables and a comparison of compositions written by university students with and without learning disabilities. Journal of Learning Disabilities, 22, 125-130. doi:10.1177/002221948902200208

Graham, S. (2006). Strategy instruction and the teaching of writing. In C.A.

MacArthur, S. Graham, \& J. Fitzgerald (Eds.), Handbook of writing research (pp. 187207). New York, NY: Guilford.

Graham, S., \& Harris, K. (1999). Assessment and intervention in overcoming writing difficulties: An illustration from the self-regulated strategy development model. Language, Speech and Hearing Services in Schools, 30, 255-264. doi:10.1044/01611461.3003.255

Graham, S., \& Perin, D. (2007). A meta-analysis of writing instruction for adolescent students. Journal of Educational Psychology, 99, 445-476. doi:10.1037/oo22o663.99.3.445

Gregg, N. (2009). Adolescents and adults with learning disabilities and ADHD: Assessment and accommodations. New York, NY: Guilford.

Gregg, N. (1986a). Cohesion: Inter and intra sentence errors. Journal of Learning Disabilities, 19, 338-341. doi:10.1177/oo22219486019006o6

Gregg, N. (1986b). College learning disabled, normal, \& basic writers' sentence combining abilities. B.c. Journal of Special Education, 10, 153-166.

Gregg, N., Bandalos, D.L., Coleman, C., Davis, J.M., Robinson, K., \& Blake, J. (2008). The validity of a battery of phonemic and orthographic awareness tasks for adults with and without dyslexia and attention deficit/hyperactivity disorder. Remedial and Special Education, 29, 175-19o. doi:10.1177/0741932508315951

Gregg, N., Coleman, C., Stennett, R.B., \& Davis, M. (2002). Discourse complexity of college writers with and without disabilities: A multidimensional analysis. Journal of Learning Disabilities, 35, 23-38. doi:10.1177/002221940203500103

Gregg, N., Coleman, C., Davis, M., \& Chalk, J.C. (2007). Timed essay writing: Implica- 
tions for high-stakes tests. Journal of Learning Disabilities, 40, 306-318. doi:10.1177/ 00222194070400040201

Gregg, N., \& Hoy, C. (1989). Coherence: The comprehension and production abilities of college writers who are normally achieving, learning disabled, \& underprepared. Journal of Learning Disabilities, 22, 370-372, 39o. doi:10.1177/0022219489022006068

Gregg, N., \& Hoy, C. (1990). Referencing: The cohesive use of pronouns in the written narrative of college underprepared writers, nondisabled writers, and writers with learning disabilities. Journal of Learning Disabilities, 23, 557-563. doi:10.1177/ o02221949002300905

Gregg, N., Hoy, C., \& Sabol, R. (1988). Spelling error patterns of normal, learningdisabled, and underprepared college writers. Journal of Psychoeducational Assessment, 6, 14-23. doi:10.1177/o7342829880o6oo102

Gregg, N., \& McAlexander, P. (1989). The relation between sense of audience and specific learning disabilities: An exploration. Annals of Dyslexia, 39, 206-226. doi:10 $.1007 / \mathrm{BFO} 2656910$

Gregg, N., Sigalas, S.A., Hoy, C., Weisenbaker, J., \& McKinley, C. (1996). Sense of audience and the adult writer: A study across competence levels. Reading and Writing, 8, 121137. doi:10.1007/BFOO423929

Guthrie, J.T., \& Wigfield, A. (2000). Engagement and motivation in reading. In M.L. Kamil, P.B. Mosenthal, P.D. Pearson, \& R. Barr (Eds.), Handbook of reading research (Vol. III, pp. 403-422). New York, NY: Erlbaum.

Halliday, M.A.K. (1973). Explorations in the functions of language. New York, NY: Elsevier. Hatcher, J., Snowling, M.J., \& Griffiths, Y.M. (2002). Cognitive assessment of dyslexic students in higher education. British Journal of Educational Psychology, 72, 119-133. doi:10.1348/00o709902158801

Hayes, J. (1996). A new framework for understanding cognition and affect in writing. In M. Levy \& S. Ransdell (Eds.), The science of writing: Theories, methods, individual differences, \& applications (pp. 1-27). Mahwah, NJ: Erlbaum.

Hoskyn, M., \& Swanson, H.L. (2003). The relationship between working memory and writing in younger and older adults. Reading and Writing, 16, 759-784. doi:10.1023/ A:1027320226283

Jacobson, E. (2008). Learning and collaborating in the adult literacy education wiki. E-Learning, 5, 370-383. doi:10.2304/elea.2008.5.4.370

Kemp, N., Parrila, R.K., \& Kirby, J.R. (2008). Phonological and orthographic spelling in high-functioning adult dyslexics. Dyslexia, 15, 105-128. doi:10.1002/dys.364

Lenhart, A. (2010). Cell phones and American adults. Retrieved from Pew Internet and American Life Project: http://www.pewinternet.org/2010/o9/o2/cell-phones-and -american-adults/

Leuenberger, J., \& Morris, M. (1990). Analysis of spelling errors by learning disabled and normal college students. Learning Disabilities Focus, 5, 103-118. 
Li, J. (2006). The mediation of technology in E SL writing and its implications for writing assessment. Assessing Writing, 11, 5-21. doi:10.1016/j.asw.2005.09.001

MacArthur, C.A., Greenberg, D., Mellard, D.F., \& Sabatini, J.P. (2010). Introduction to the special issue on models of reading component skills in low literate adults. Journal of Learning Disabilities, 43, 99-100. doi:10.1177/oo22219409359340

MacArthur, C.A., \& Philippakos, Z.A. (2013). Self-regulated strategy instruction in developmental writing: A design research project. Community College Review, 41, 176-195. doi:10.1177/oog1552113484580

Mather, N., \& Wendling, B.J. (2011). How SLD manifests in writing. In D.P. Flanagan \& V.C. Alfonso (Eds.), Essential of specific learning disability identification (pp. 65-88). Hoboken, NJ: Wiley.

McGrew, K.S., \& Knopik, S.N. (1993). The relationship between wJ-R Gf-Gc cognitive clusters and writing achievement across the life-span. School Psychology Review, 22, 687-695.

McGrew, K.S., \& Wendling, B.J. (2010). Cattell-Horn-Carroll cognitive-achievement relations: What we have learned from the past 20 years of research. Psychology in the Schools, 47, 651-675. doi:10.1002/pits.20497

Meyler, A., \& Breznitz, Z. (2003). Processing of phonological, orthographic and crossmodal word representations among adult dyslexics and normal readers. Reading and Writing, 16, 785-803. doi:10.1023/A:1027336027211

Morris-Friehe, M., \& Leuenberger, J. (1992). Direct and indirect measures of writing for nonlearning disabled and learning disabled college students. Reading and Writing, 4, 281-296. doi:10.1007/BFo1027152

Meyer, D.K., \& Turner, J.C. (2006). Re-conceptualizing emotion and motivation to learn in classroom contexts. Educational Psychology Review, 18, 377-39o. doi:10.1007/ s10648-oo6-9o32-1

Miller, B., McCardle, P., \& Hernandez, R. (2010). Advances and remaining challenges in adult literacy research. Journal of Learning Disabilities, 43, 101-107. doi:10.1177/ oo22219409359341

National Council of Teachers of English. (2008). 21st century curriculum and assessment framework. Retrieved from National Council of Teachers of English Position Statements: http://www.ncte.org/positions/statements/21stcentframework

National Research Council (2012). Improving adult literacy instruction: Options for practice and research. Washington, DC: The National Academies Press.

Pajares, F. (2003). Self-efficacy beliefs, motivation, and achievement in writing: A review of the literature. Reading and Writing Quarterly, 19, 139-158. doi:10.108o/ 10573560308222

Pajares, F., \& Valiante, G. (2006). Self-efficacy beliefs and motivation in writing. In C.A. MacArthur, S. Graham, \& J. Fitzgerald (Eds.), Handbook of writing research (pp. 158-170). New York, NY: Guilford. 
Pennington, B.F., McCabe, L.L., Smith, S.D., Lefly, D.L., Bookman, M.O., ... Lubs, H.A. (1986). Spelling errors in adults with a form of familial dyslexia. Child Development, 57, 1001-1013. doi:10.2307/1130374

Perin, D. (2013). Literacy skills among academically underprepared students. Community College Review, 41, 118-136. doi:10.1177/oog1552113484057

Peverly, S.T. (2006). The importance of handwriting speed in adult writing. Developmental Neuropsychology, 29, 197-216. doi:10.1207/s15326942dn2901_10

Pintrich, P.R., \& Garcia, T. (1991). Student goal orientation and self-regulation in the college classroom. In M.L. Maehr \& P.R. Pintrich (Eds.), Advances in motivation and achievement. Goals and self-regulatory processes (Vol. 7, pp. 371-402). Greenwich CT: JAI Press.

Pintrich, P.R. (2000). The role of goal orientation in self-regulated learning. In M.

Boekaerts, P. Pintrich, \& M. Zeidner (Eds.), Handbook of self-regulation (pp. 452-502). New York, NY: Academic Press.

Powell, D., \& Dixon, M. (2011). Does s Ms text messaging help or harm adults' knowledge of standard spelling? Journal of Computer Assisted Learning, 27, 58-66. doi:10.1111/ j.1365-2729.2010.00403.x

Prior, P. (2006). A sociocultural theory of writing. In C. MacArthur, S. Graham, \& J. Fitzgerald (Eds.), Handbook of writing research (pp. 54-65). New York, NY: Guilford.

Puranik, C.S., Lombardino, L.J., \& Altmann, L.J. (2007). Writing through retellings: An exploratory study of language-impaired and dyslexic populations. Reading and Writing, 20, 251-272. doi:10.1007/s11145-0o6-9o30-1

Ranker, J. (2008). Composing across multiple media: A case study of digital video production in a fifth grade classroom. Written Communication, 25, 196-234. doi:10.1177/ o741088307313021

Rubin, D., \& Looney, J. (1990). Facilitation of audience awareness: Revision processes of basic writers. In G. Kirsch \& D. Roen (Eds.), A sense of audience in written communication (pp. 280-292). Thousand Oaks, CA: Sage.

Schneider, W.J., \& McGrew, K.S. (2012). The Cattell-Horn-Carroll model of intelligence. In D. Flanagan \& P. Harrison (Eds.), Contemporary intellectual assessment: Theories, tests, and issues (3rd ed., pp. 99-144). New York: Guilford.

Smith, J.O. (1993). Self-reported written language difficulties of university students with learning disabilities. Journal on Postsecondary Education and Disability, 10, 1-10.

Swanson, H., \& Hsieh, C-J. (2009). Reading disabilities in adults: A selective metaanalysis of the literature. Review of Educational Research, 79(4), 1362-139o. doi:10 .3102/o034654309350931.

Swanson, H.L., \& Siegel, L. (2001). Learning disabilities as a working memory deficit. Issues in Education, 7, 107-129.

Tops, W., Callens, M., Bijn, E., \& Brysbaert, M. (2014). Spelling in adolescents with 
dyslexia: Errors and modes of assessment. Journal of Learning Disabilities, 47, 2953o6. doi:10.1177/oo22219412468159

Tops, W., Callens, M., Van Cauwenberghe, E., Adriaens, J., \& Brysbaert, M. (2013). Beyond spelling: The writing skills of students with dyslexia in higher education. Reading and Writing, 26, 705-720. doi:10.1007/s11145-012-9387-2

Torrance, M., \& Galbraith, D. (2006). The processing demands of writing. In C.A. MacArthur, S. Graham, \& J. Fitzgerald (Eds.), Handbook of writing research (pp. 67-80). New York, NY: Guilford.

Traxler, M., \& Gernsbacher, M. (1993). Improving written communication through perspective-taking. Language and Cognitive Processes, 8, 311-344. doi:10.108o/ o169o969308406958

Turner, K.H. (2010). Digitalk: A new literacy for a digital generation. Phi Delta Kappan, 92, 41-46. Retrieved from http://www.kappanmagazine.org/content/92/1/ 41.abstract

Turner, K.H. (2011). Digitalk: Community, convention, \& self-expression. In J. Rowsell \& S.A. Abrams (Eds.), Rethinking identity and literacy education in the 21st century (pp. 263-282). New York, NY: Teachers College Record Yearbook.

Turner, K.H., Abrams, S.S., Katic, E., \& Donovan, M.J. (2014). Demystifying digital: The what and why of the language teens use in digital writing. Journal of Literacy Research, 46, 1-37. doi: 10.1177.1086296X14534061

Vogel, S.A. (1985). Syntactic complexity in written expression of LD college writers. Annals of Dyslexia, 35, 137-157. doi:10.1007/BFo2659184

Vogel, S.A., \& Moran, M.R. (1982). Written language disorders in learning disabled college students. In W. Cruickshank \& J. Lerner (Eds.), Coming of age: The best of ACLD (Vol. 111, pp. 221-255). Syracuse, NY: Syracuse University Press.

Vygotsky, L. (1986). Thought and language. Cambridge, MA: MIT Press.

Vrugt, A., Oort, F., \& Zeeberg, C. (2002). Goal orientations, perceived self-efficacy and study results among beginner and advanced students. British Journal of Educational Psychology, 72, 385-397. doi:10.1348/00o709902320634285

Wengelin, A. (2007). The word-level focus in text production by adults with reading and writing difficulties. In G. Rijlaarsdam (Series Ed.) and M. Torrance, L. van Waes, \& D. Galbraith (Volume Eds.), Writing and cognition: Research and applications (Studies in Writing, Vol. 2o, pp. 67-82). Amsterdam, Elsevier.

Wood, C., Kemp, N., Waldron, S., \& Hart, L. (2014). Grammatical understanding, literacy, and text messaging in school children and undergraduate students: A concurrent analysis. Computers \& Education, 70, 281-29o. doi: 10.1016/j.compuedu.2013.o9 .003

Zhang, S., \& Duke, N.K. (2008). Strategies for Internet reading with different reading purposes: A descriptive study of twelve good internet readers. Journal of Literacy Research, 40 (1), 128-162. doi:10.108o/10862960802070491 
Zimmerman, B.J., \& Risemberg, R. (1997). Becoming a self-regulated writer: A social cognitive perspective. Contemporary Educational Psychology, 22, 73-101. doi:10.10o6/ ceps.1997.0919 